\title{
Air Quality, Health and Community Action
}

\author{
Larry E. Erickson"1, Wendy Griswold ${ }^{2}$, Ronaldo G. Maghirang1, Brian P. Urbaszewski ${ }^{3}$ \\ ${ }^{1}$ Kansas State University, Manhattan, KS, USA \\ ${ }^{2}$ University of Memphis, Memphis, TN, USA \\ ${ }^{3}$ Respiratory Health Association, Chicago, IL, USA \\ Email: lerick@ksu.edu,wgrswold@memphis.edu,rmaghir@ksu.edu,BUrbaszewski@lungchicago.org
}

How to cite this paper: Erickson, L.E., Griswold, W., Maghirang, R.G. and Urbaszewski, B.P. (2017) Air Quality, Health and Community Action. Journal of Environmental Protection, 8, 1057-1074. https://doi.org/10.4236/jep.2017.810067

Received: August 11, 2017

Accepted: September 15, 2017

Published: September 18, 2017

Copyright ( 92017 by authors and Scientific Research Publishing Inc. This work is licensed under the Creative Commons Attribution International License (CC BY 4.0).

http://creativecommons.org/licenses/by/4.0/

c) (i) Open Access

\begin{abstract}
Air quality is impacting health in many cities in most countries because of particulate pollution, sulfur dioxide, nitrogen dioxide, and ozone. Very small particulates from engine emissions and coal fired electric power plants enter the lungs and pollute the blood of urban residents leading to a burden of disease with more than 3 million premature deaths per year attributed to outdoor air pollution. Welfare losses including premature deaths associated with air pollution were about $\$ 5$ trillion in 2013. A global transition to electric vehicles, and the generation of electricity without combustion emissions would improve air quality significantly and reduce greenhouse gas emissions. This transition is in progress in many parts of the world with more than 2 million electric vehicles in service in 2017. Electric bus and electric taxi sales are increasing, and many large cities have multiple programs to improve air quality. When health costs are considered, it is very appropriate for communities to take action to improve air quality and health. This work reviews and reports many positive actions that are in progress in larger cities.
\end{abstract}

\section{Keywords}

Air Pollution, Particulates, Air Quality, Health, Electric Vehicles, Solar, Disease, Cities, Urban

\section{Introduction}

Reducing greenhouse gas emissions and improving air quality are significant global challenges. This review addresses air quality, the impact of air pollution on health, and community actions to improve air quality and associated health equity [1]-[98].

Air pollution is a global concern with social costs of the order of $\$ 3$ trillion/year [21] [22] [43] [51] [58]. There are about 3.3 million premature deaths 
per year due to outdoor air pollution, and particulate matter (PM2.5) is one of the most important air pollutants [48]. Most major urban centers have concentrations of particulates that are above the recommended World Health Organization Air Quality Guideline of 10 micrograms per cubic meter $\left(\mu \mathrm{g} / \mathrm{m}^{3}\right)$ [21] [22] [94]. Reducing PM2.5 concentrations to less than the WHO guidelines would prevent an estimated 2.1 million deaths per year [4] [80]. The health care expenses associated with poor air quality would be reduced significantly if urban air quality were improved to meet regulatory values [80]. A relatively new World Bank/Institute for Health Metrics and Evaluation study estimates that the welfare losses due to deaths from air pollution were about $\$ 5$ trillion in 2013 [80] [96]. The American Lung Association of California has reported that air pollution attributed to passenger vehicles had an estimated harm of $\$ 24$ billion for health and $\$ 13$ billion for climate in 2015 in the states of California, Connecticut, Maine, Maryland, Massachusetts, New Jersey, New York, Oregon, Rhode Island, and Vermont [38]. This group of states is working cooperatively to encourage electric vehicle adoption and reductions in vehicle emissions. In the United States, there are about 200,000 premature mortalities per year with emissions from vehicles and coal burning power plants being the most significant sources [15]. Air pollution from burning coal includes small particulates containing sulfur and nitrogen compounds. The largest source of sulfur emissions is coal combustion [15].

One purpose of this manuscript is to help residents of urban communities in their efforts to understand the air quality where they live, work, and play. Many residents of large cities do not realize that particulates in air have been reported to be the fifth largest overall global risk factor for premature mortality [34]. Another purpose of this manuscript is to provide information on the health effects of air pollution. The third goal of the manuscript is to include some information on actions that can be taken to improve air quality in urban communities.

Urban cities and metropolitan areas can have air quality management plans (AQMP), which include air quality objectives, monitoring, emission inventory, prediction tools, control strategies, and public participation [32] [81]. Improvements in air quality can be achieved by implementation of the AQMP to accomplish goals that are important for the community.

\section{Air Quality in Urban Communities}

Particulates (PM2.5), nitrogen dioxide $\left(\mathrm{NO}_{2}\right)$, ozone $\left(\mathrm{O}_{3}\right)$, carbon monoxide (CO), and sulfur dioxide $\left(\mathrm{SO}_{2}\right)$ are the most common air pollutants in urban communities [23] [85] [87]. These pollutants are included in the air quality index (AQI) that has been developed to inform residents about air quality in their communities [85]. The index has 6 categories with a color for each: good, moderate, unhealthy for sensitive groups, unhealthy, very unhealthy, and hazardous [85]. The corresponding colors are green, yellow, orange, red, purple, and maroon. The U.S. EPA has established National Ambient Air Quality Standards 
(NAAQS) for each criteria pollutant [87]. The NAAQS for $\mathrm{NO}_{2}, \mathrm{O}_{3}$, and particulates are shown in Table 1. In Table 1, the primary standards are to protect public health, including that of more sensitive populations such as asthmatics. Secondary standards are to provide public welfare protection, including damage to plants and animals [87]. The AQI for $\mathrm{NO}_{2}, \mathrm{O}_{3}$, and particulates is shown in Table 2. The European Commission of the European Union has developed air quality standards for the countries in the European Union [20]. The air quality standards are designed to protect human health and public welfare (i.e., effects on vegetation, weather, visibility, etc.).

Table 1. National Ambient Air Quality Standards for PM2.5, nitrogen dioxide $\left(\mathrm{NO}_{2}\right)$, and ozone $\left(\mathrm{O}_{3}\right)$ [87].

\begin{tabular}{|c|c|c|c|c|}
\hline Pollutant & $\begin{array}{l}\text { Primary/ } \\
\text { Secondary }\end{array}$ & $\begin{array}{l}\text { Averaging } \\
\text { Time }\end{array}$ & Level & Form \\
\hline Nitrogen & Primary & 1 hour & $100 \mathrm{ppb}$ & $\begin{array}{l}98^{\text {th }} \text { percentile of } 1 \text {-hour daily maximum } \\
\text { concentrations, averaged over } 3 \text { years }\end{array}$ \\
\hline Dioxide $\left(\mathrm{NO}_{2}\right)$ & $\begin{array}{c}\text { Primary and } \\
\text { Secondary }\end{array}$ & 1 year & $53 \mathrm{ppb}$ & Annual Mean \\
\hline Ozone $\left(\mathrm{O}_{3}\right)$ & $\begin{array}{l}\text { Primary and } \\
\text { Secondary }\end{array}$ & 8 hours & $0.070 \mathrm{ppm}$ & $\begin{array}{c}\text { Annual fourth-highest daily maximum } \\
\text { 8-hour concentration, averaged over } 3 \\
\text { years }\end{array}$ \\
\hline \multirow{3}{*}{$\begin{array}{l}\text { Particle } \\
\text { Matter }\end{array}$} & Primary & 1 year & $12.0 \mu \mathrm{g} / \mathrm{m}^{3}$ & Annual mean, averaged over 3 years \\
\hline & $\begin{array}{l}\text { Primary and } \\
\text { Secondary }\end{array}$ & 24 hours & $35 \mu \mathrm{g} / \mathrm{m}^{3}$ & $98^{\text {th }}$ percentile, averaged over 3 years \\
\hline & $\begin{array}{l}\text { Primary and } \\
\text { Secondary }\end{array}$ & 24 hours & $150 \mu \mathrm{g} / \mathrm{m}^{3}$ & $\begin{array}{c}\text { Not to be exceeded more than once per } \\
\text { year on average over } 3 \text { years }\end{array}$ \\
\hline
\end{tabular}

Table 2. Air quality index (AQI) [87].

\begin{tabular}{|c|c|c|c|c|}
\hline AQI Categories & Health Concern & Ozone (ppm) & PM2.5 $\left(\mu \mathrm{g} / \mathrm{m}^{3}\right)$ & $\mathrm{NO}_{2}(\mathrm{ppb})$ \\
\hline Good (up to 50 ) & Air quality is satisfactory & $0-0.054$ & $0-12.0$ & $0-53$ \\
\hline & $\begin{array}{c}\text { Air quality is acceptable; } \\
\text { however, unusually sensitive }\end{array}$ & & & \\
\hline Moderate (51-100) & $\begin{array}{l}\text { people should consider } \\
\text { reducing prolonged or heavy } \\
\text { exertion. }\end{array}$ & $0.055-0.070$ & $12.1-35.4$ & $54-100$ \\
\hline Unhealthy for & $\begin{array}{l}\text { People with heart and lung } \\
\text { disease, older adults and }\end{array}$ & & & \\
\hline $\begin{array}{l}\text { Sensitive Groups } \\
\quad(101-150)\end{array}$ & $\begin{array}{l}\text { children are at a greater risk } \\
\text { from exposure to ozone and } \\
\text { particulate matter. }\end{array}$ & $0.071-0.085$ & $35.5-55.4$ & $101-360$ \\
\hline $\begin{array}{l}\text { Unhealthy } \\
(151-200)\end{array}$ & $\begin{array}{l}\text { Everyone may begin to expe- } \\
\text { rience some adverse health } \\
\text { effects, and those in the sensi- } \\
\text { tive groups may experience } \\
\text { more serious health effects. }\end{array}$ & $0.086-0.105$ & $55.5-150.4$ & $361-649$ \\
\hline $\begin{array}{l}\text { Very Unhealthy } \\
(201-300)\end{array}$ & $\begin{array}{l}\text { Everyone may experience } \\
\text { more serious health effects }\end{array}$ & $0.106-0.200$ & $150.5-250.4$ & $650-1249$ \\
\hline $\begin{array}{l}\text { Hazardous } \\
(301-500)\end{array}$ & $\begin{array}{c}\text { Entire population is more } \\
\text { likely to be affected. }\end{array}$ & - & $250.5-500.4$ & $1250-2049$ \\
\hline
\end{tabular}




\subsection{Particulate Matter in Air}

Particulate matter in air is one of the most important air pollutants. The U.S. EPA NAAQS for particulates that are 2.5 micrometers $(\mu \mathrm{m})$ in equivalent aerodynamic diameter or smaller (PM2.5) are $12 \mu \mathrm{g} / \mathrm{m}^{3}$ (annual average) and 35 $\mu \mathrm{g} / \mathrm{m}^{3}$ (24-hour average) [87]. The air quality index (AQI) for PM2.5 has a value of 50 when PM2.5 is equal to 12 for the transition value from green to yellow and a value of 100 when PM2.5 is equal to 35.4 for the transition value from yellow to orange. The AQI value of 100 corresponds to the 24 hour PM2.5 NAAQS value of $35 \mu \mathrm{g} / \mathrm{m}^{3}$ [85].

Particulate matter impacts on health depend on the size distribution of the particulates and the chemicals that make up the particulates. The size of particulates from internal combustion vehicle emissions are very small compared to dust from soil. Particulates associated with vehicle emissions range from about 10 nanometers (nm) to $700 \mathrm{~nm}$ [44] [46] [97]. Because of their small size they pass into the smaller parts of the lung and some find their way into the blood stream and the brain [10]. Particulates with equivalent aerodynamic diameters in the range of 5 to $100 \mathrm{~nm}$ are defined as ultrafine particles [12]. Carbon compounds from diesel exhaust in particulates have been identified with increases in the number of cases of lung cancer [2] [10] [22] [40].

Concentrations of particulate matter in major cities in micrograms per cubic meter are well above the WHO recommended value of $10 \mu \mathrm{g} / \mathrm{m}^{3}$; annual average values include 170 for Delhi, 66 for Cairo, 55 for Beijing, 19 for Los Angeles, and $13 \mu \mathrm{g} / \mathrm{m}^{3}$ for Chicago [22] [45]. Values of particulate matter are strongly associated with vehicle emissions and traffic density. Concentrations are larger near freeways and roads with many vehicles [21].

\subsection{Nitrogen Dioxide in Air}

The regulatory concentrations of nitrogen dioxide in ambient air are 100 parts per billion (ppb) or $188 \mu \mathrm{g} / \mathrm{m}^{3}$ (1 hour average value) and $53 \mathrm{ppb}$ or $100 \mu \mathrm{g} / \mathrm{m}^{3}$ (annual mean value) [87]. The Air Quality Index has the good range (AQI from 0 to 50 ) from 0 to $53 \mathrm{ppb}$ and the moderate range (AQI from 51 to 100) from 54 to $100 \mathrm{ppb}$ for nitrogen dioxide [85].

About $58 \%$ of nitrogen oxides in urban air are attributed to mobile sources [23]. Other combustion sources also have emissions of nitrogen oxides. Since nitrogen dioxide emissions are associated with vehicle emissions, the concentrations in urban air vary with time of day and traffic density.

\subsection{Ozone in Air}

Ozone is produced in urban air by photochemical reactions when hydrocarbons and nitrogen oxides are present from vehicle emissions and other sources [23]. The regulatory concentration for ozone is 0.070 parts per million (ppm) or 70 ppb. This is an 8 hour average value. The regulation is written such that this average value may happen on up to three days per year averaged over three years 
[87]. The Air Quality Index has the good range (AQI from 0 to 50) from 0 to $0.054 \mathrm{ppm}$ and the moderate range (AQI from 51 to 100) from 0.055 to 0.07 ppm [85].

\subsection{Traffic Density and Air Quality}

Air quality is impacted by stationary point sources such as coal fired power plants, industrial smoke stacks and mobile sources such as vehicles. Since traffic density varies with location and time of day, there will be variations in air quality that depend on how close vehicle emissions are to the instruments that are making air quality measurements. There are several studies that report air quality data near roads and streets [7] [11] [12] [63]. Particulate numbers and concentrations are significantly larger near major freeways and highways, and values vary with traffic density. There is often a concentration gradient over a distance of about 100 to 300 meters with much smaller particulate concentrations 100 meters away from the road [12]. Air quality parameters measured near roads are commonly significantly larger than those measured at fixed regulatory monitoring sites; values twice as large near roads have been reported [11].

\section{Health Effects of Air Pollution}

Since air pollution includes particulates, sulfur dioxide, nitrogen oxides and ozone epidemiology studies are impacted by more than one pollutant in many cases. It is well known that these pollutants are causally related to cardiovascular disease [10]. Individuals with asthma and/or chronic obstructive pulmonary disease may be impacted by these pollutants in the air they breathe. Lung cancer mortality is associated with particulates from diesel engines [2] [10] [22].

There is evidence that compounds in urban air pollutants move from the lungs to the blood stream and the brain [10,29]. Decreased cognitive function, autism in children, Parkinson's disease, and dementia are identified as being more prevalent in large cities because of air pollution [10] [14] [21] [61] [79]. Traffic related studies have reported that dementia is associated with air pollution from vehicles including small particulates [18]. The association of Parkinson's disease with air pollution appears to be not as strong as with dementia [10] [18] [29] [68]. About 47 million people worldwide are living with dementia, and the estimated annual cost is $\$ 818$ billion [65].

There are several studies that report an increase in the percent of children with autism because of increased concentrations of air pollutants [6] [66] [69] [90]. The associations were stronger for boys than girls [69]. The third trimester of pregnancy appears to have the strongest association with the health impact of the concentration of air pollutants on autism [66]. Living near a freeway was associated with autism [90]. Traffic sources of air pollution were significant in the study by Becerra et al. [6].

There are significant effects of air pollution due to PM2.5 and ozone on adverse birth outcomes [27] [33] [55]. The risks associated with low birth weight, 
preterm delivery, and very preterm delivery are greater for babies of women who are exposed daily to high concentrations of PM2.5 while pregnant [33]. Ozone appears to increase the risk of early delivery, but it decreases the risk of term low birth weight [33]. The estimated annual cost of preterm births associated with air pollution in the United States has been estimated to be about $\$ 5$ billion with an estimated $3.32 \%$ of the preterm births attributed to PM2.5 being greater than 8.8 micrograms per cubic meter [77]. Sulfur dioxide contributed to low birth weight babies in China [91].

Childhood leukemia appears to have an association with air pollution. There may be exposures to air pollution during pregnancy and after birth. Traffic-related air pollution studies have shown an association of traffic density with childhood leukemia [26] [30] [35].

Multiple sclerosis (MS) is a neurological disorder and chronic inflammatory disease of the central nervous system that has been associated with air pollution [10] [29] [57]. Research has found a relationship between air pollutants including PM and MS relapses [29] [36] [53] [60] [89]. Cigarette smoking and smoke have also been identified as exposures with associated health impacts for those who have MS [59].

Recently, the literature related to air pollution and autoimmune disease development has been reviewed for rheumatoid arthritis (RA), juvenile idiopathic arthritis (JIA), and systematic autoimmune rheumatic diseases (SARDs) [75]. An association between PM2.5 air pollution and SARDs was found [8] [9]. For children less than 5.5 years, an association was found for JIA and PM2.5 [98]. Further research is suggested on the effect of air pollution on autoimmune diseases [75].

Data from the Global Burden of Disease Study 2013 has been used to estimate the stroke-related disability adjusted life-years (DALYs) associated with a number of risk factors worldwide from 1990 to 2013 [25]. Globally, 29.2\% of the burden of stroke was attributed to air pollution [25]; this included both ambient air pollution and household air pollution from solid fuels. Almost $22 \%$ of stroke related DALYs were attributed to ambient PM2.5 air pollution in China and India compared to $10.2 \%$ in high income countries [25]. The total number of DALYs in 2013 was about 102 million for stroke; more than 80\% of these were from low-income and middle-income countries [25].

The health impacts associated with air pollution may be difficult to measure because of other factors that also affect health such as level of education, psychosocial stressors and quality of medical care [56]. Air quality varies within cities and low income communities often have higher air pollutant concentrations in their neighborhoods. There is no safe level of exposure to some air pollutants [67].

\section{Improving Air Quality}

There are a number of actions that can be taken to improve urban air quality. 
Since coal combustion is an important source of air pollutants, the transition from coal to wind and solar energy for generation of electricity is a high priority. A number of communities have programs in place with a goal to reduce emissions and air pollutant concentrations. In California, there are ongoing efforts to advance the electrification of transportation with incentives for residents to purchase electric vehicles and programs to encourage solar generation of electricity [16] [21] [22] [23]. California has an extensive electric vehicle charging infrastructure, including shaded parking where solar panels are producing electricity in parking lots that include charging equipment [23].

The global issue of greenhouse gas emissions and climate change would benefit if all large cities worked to improve their air quality by transitioning to electric powered transportation and if the electricity was generated without combustion using wind and solar energy, hydro and nuclear power. Some progress is being made as described below.

The U.S. EPA has a research program at the nexus of reducing greenhouse gas emissions and improving air quality [82] [83]. Research to prevent and reduce air emissions in urban areas is one of the goals of the strategic plan, which addresses the challenge of protecting health and the environment from the impacts of climate change and air pollution.

\subsection{Electric Buses}

There are several companies that are making electric buses for use in cities, and the buses are economical for cities to purchase and use [22]. New Flyer Industries, Proterra, Volvo, and BYD are in competition to expand their sales of electric buses. Proterra is a new U.S. company that has met California's zero emission bus rules [22]. BYD is a Chinese company that has plants in Lancaster, California and Komarom, Hungary. When the health benefits are considered, electric buses are very logical choices for large cities that are working to improve their air quality.

There are two approaches to charging the batteries on electric buses. One is to have a sufficient charge on the battery to only need to charge them each evening. The other alternative is to have wireless charging at locations where the bus stops along the route. One of the important efforts that is being addressed is the need for international standards for charging buses [41]. Solar panels can be installed at bus stops to provide shade and cover for those who are waiting for the bus and to generate electric power that can be stored in batteries at charging locations along the bus route.

Chicago Transit Authority purchased two electric buses from New Flyer Industries and placed them in service in October 2014 [19] [22]. The buses have $300 \mathrm{kWh}$ Li-ion batteries and a safety and performance battery management system. The batteries can be charged each evening in 3 to 5 hours. The estimated service life is 12 years. The buses have a modern electric power steering system which is expected to reduce maintenance and repairs [19]. The estimated health 
benefits per bus per year are estimated to be about $\$ 55,000$ because of the reduced emissions of particulates, and nitrogen oxides [19]. The buses have performed well and the Chicago Transit Authority is planning to purchase additional electric buses.

London has made progress in its efforts to electrify transportation and reduce air pollution. This includes a transition to electric buses with 51 added in September 2016, and a plan to continue to bring additional electric buses into service until all 300 single-deck buses are electric buses and 3100 double-deckers are hybrid-electric buses [41] [50] [76]. When these 51 new buses are added to the existing 22 all-electric buses, there are 73 electric buses with the 22 serving outer London [76]. The motivation for the transition to electric buses is because of the need to improve air quality. Reductions in particulate matter and nitrogen oxides in air are the two pollutants of greatest concern [76].

There has been positive progress in many other communities to transition to electric buses. In China, sales of new electric buses were more than 100,000 in 2016 [5]. Seattle, Washington has plans to purchase up to 120 all electric buses, with initial orders from several companies to gather information on the relative quality of the different buses that are available [47]. Reduced emissions, better air quality, and quieter ride have been identified as positive features of the electric buses [22].

\subsection{Electric Taxi Cabs}

One of the ways to reduce emissions and improve air quality is to transition to electric taxi cabs. A new factory designed to produce 20,000 electric taxi cabs per year for London and other cities is being built in central England [28]. The plan to transition to electric taxi cabs is supported by some government funding because of the desire to improve air quality in London and other cities. London has a daily fee for motor vehicles that enter the congested core of the city during weekday business hours. This fee is to reduce congestion, and it has higher fees for polluting vehicles in order to improve air quality [88]. Fees on vehicles associated with air quality goals can be used as an incentive to encourage electric taxi cabs as well as other electric vehicles.

There is a plan in Beijing, China to convert all of the taxi cabs to electric vehicles. All new taxi cabs are to be electric vehicles with the estimated cost of 67,000 new cabs being about $\$ 1.3$ billion [49]. BYD has been testing electric taxis in several large cities in China. Air quality issues are one of the reasons for this effort. The national government has a new energy vehicle campaign to encourage both plug-in hybrid and electric vehicle sales [49].

Electric vehicles are being used for taxi cabs in Montreal, Canada, New York City, Austin Texas, Amsterdam, Budapest, Barcelona, Prague, Rome, Stockholm, and many other places [52] [78]. Many cities are attempting to improve air quality by encouraging electric taxi cabs.

As the technology for wireless charging develops, it will be possible to have 
wireless charging while taxi cabs are waiting for customers at locations where there is frequent demand for passengers. Solar panels over these locations can be used to provide shaded charging and electricity. There can be energy storage at these locations also.

Newer ride share services such as Uber and Lyft have the potential to transition to electric vehicles and help with efforts to improve air quality and their image.

\subsection{Other Ways to Improve Air Quality}

There are many additional actions that can be taken to improve air quality and reduce emissions in communities. One approach is to reduce vehicle emissions by promoting walking and bicycle riding. Good sidewalks, bike lanes, and bike paths away from traffic encourage increased walking and cycling. Parking for bicycles is also important. The integration of biking and public transportation to allow bicycles on public transport systems is helpful. Electric bicycles should be promoted by having covered parking and charge stations. Bicycle share programs in which bicycles are available for riding from one place to another can be established in communities [37].

Low emission zones in cities where vehicles that do not meet emission standards are restricted from entering have been established in many cities [37] [92]. Car-free zones have been established in many cities as well.

One significant approach to improving urban air quality is to increase the amount of vegetation in urban areas along streets, in parks, with green roofs, and on balconies [54] [71]. Vegetation provides surfaces for particulates and gases to adsorb (stick to the surface of) and absorb (soak into) [42] [72]. Parks provide areas away from traffic emissions for people to exercise [73]. The literature related to the air quality benefits of green infrastructure in cities has been reviewed by Abhijith et al. [1]. Hedges along roads are recommended as a green solution that allows for the adsorption of pollutants to vegetation and the dispersion of the air.

Los Angeles, California has been working to reduce air pollution for about 50 years [62]. Progress toward better air quality has been made by mandating reductions in nitrogen oxide and sulfur oxide emissions from refineries, promoting electric vehicles, providing rideshare incentives, developing a clean up green up program to add vegetation, to get all electrical energy from renewable sources, to implement a clean air action plan to reduce air emissions at the Port of Los Angeles and the Port of Long Beach, to accurately identify sources of air pollution, and invest in strategies and technologies with multiple objectives regarding air quality air toxics, transportation, energy, and climate change [62]. In July 2017 the Metropolitan Transportation Authority decided to purchase 95 electric buses for use in Los Angeles County [99].

Public education on the health impacts of air pollution and actions that can be taken is recommended because many people do not understand the impact of air 
pollution on health [39]. Greater health awareness has the potential to change behavior and reduce vehicle emissions. Investment in cleaner vehicles and electric vehicles, reducing diesel idling, working from home, public transport subsidization, integration of government policies, and effective community participation in decision making have been identified as being beneficial in efforts to improve air quality [22] [39]. Recent developments in low cost air sensors make community monitoring a more affordable activity for educating residents about local air quality issues [95]. Increased knowledge and awareness of local health impacts and air quality has the potential to support meaningful participation in decision making at the community level and beyond. Several communities in the U.S. are engaged in community-based participatory research to determine how effective these new technologies are in supporting community learning and action related to air quality improvements [86].

The Air Quality Index (AQI) is used throughout the world to provide public information on air quality. Values from continuous monitoring are available on the Internet to inform the public about air quality in many locations [3] [93]. In some locations LED (light emitting diode) displays provide information on local air quality by reporting current local values of the AQI [70].

Local air quality can be included in the set of information that is used in making decisions. Senate Bill 352 in the State of California considers air quality in land-use decisions for new schools by not having schools along major roads [31]. Communities can include health considerations associated with air quality in community planning.

Personal behavior can impact the extent of exposure to air pollution associated with transportation. Some things individuals can do include avoiding rush hour traffic, checking air quality for current and projected readings, exercise in parks rather than along busy roads, consider air quality when deciding where to live, consider air quality and traffic density when making travel plans, filter the air in your home, keep windows closed if the outdoor air is poor, consider air quality for where your children play [73].

There are four recent publications that address actions that communities and/or governments can take to improve air quality and health [13] [17] [39] [92]. A tool has been developed to facilitate the assessment of health impacts of outdoor air pollution interventions by non-public health experts. Six categories of modifying factors have been identified: sources of emissions, quantity of emissions, concentrations of emitted pollutants, spatial distribution, personal exposure, and individual vulnerability [17]. This tool is intended to help municipal decision makers and program planners make better decisions as they design and evaluate proposed interventions to improve air quality.

In the process of searching for good practices to improve urban air quality, it is valuable to understand the community where new practices are to be implemented. Shandas et al. [74] have made use of spatial analysis to understand the community structure, population distribution, and air quality at the neighbor- 
hood scale. They have then selected technologies to improve air quality such as planting trees to enhance local air quality by adsorbing particulates.

A systematic review of 15 recent publications resulted in four strategies to improve urban air quality: general regulations on air emissions, road traffic related interventions, energy generation related interventions, and greenhouse gas emission reduction interventions [92]. Particulate matter and nitrogen dioxide were the pollutants of greatest concern in these 15 papers. Regulations and guidelines to reduce PM2.5 have resulted in improved air quality. The establishment of low emission zones and congestion charging schemes have been successful in reducing PM2.5 and nitrogen dioxide concentrations in the areas of the cities where they have been implemented. More than 200 low emission zones have been implemented in Europe [92]. Regulations that encourage electric vehicle purchase and use in cities improve air quality and reduce greenhouse gas emissions.

In homes and buildings, high efficiency filters can be used and better air intake locations for large buildings can be selected. Air intakes on roof tops or on sides of the building away from traffic should be considered [13].

Better understanding of the impact of air pollution on health in urban communities is identified as being important [39]. Better understanding can lead to better alignment of policies and measures to reduce air pollution with protecting and improving health. One potential action is to improve the quality and coordination of public transport services so they are more convenient and cost effective [39].

Another important community action that may have great impact is to promote a transition to electric vehicles (EVs) by providing incentives to purchase EVs, adding solar powered charging infrastructure in parking lots, and holding community education events that help residents understand the health benefits of reducing emissions. Adding solar panels and charging stations in parking lots has immediate benefits including clean electricity generation, shaded parking and charging infrastructure for EVs [23]. The shaded parking is beneficial because electric vehicle charging in the shade is better for the batteries in hot environments. Because of the decrease in costs of solar panels and batteries for EVs, there is the potential for a rapid transition to communities with a significant fraction of cars being EVs and many parking lots with solar powered charging stations [22]. The solar generated electricity and the car batteries in EVs can be mutually beneficial with the batteries being used as a repository for electric power that needs to be stored and the solar power providing clean power for EVs. Real time prices for electricity that encourage battery charging when prices are low are needed to encourage EV owners to charge their batteries at the best time [23].

The transition to electric vehicles may be encouraged by government policy. The United Kingdom, France, India, and Norway have announced plans to end the sale of new gasoline and diesel automobiles at a future date [24] [64]. Nor- 
way plans for all new passenger cars and vans sold in 2025 to be zero emission vehicles. In India every vehicle sold in the country in 2030 should be powered by electricity. France plans to end the sale of gasoline and diesel vehicles in 2040 [24]. The United Kingdom plans to end the sale of new gasoline and diesel cars in 2040 [64].

In the United States, the U.S. EPA has assisted with community efforts to improve air quality through the Community Air Risk Reduction Initiative (CARRI), the Community Action for a Renewed Environment (CARE) program, and the National Clean Diesel Campaign [83].

\section{Conclusions}

The particulates from vehicle emissions are very small with dimensions from about 10 to $700 \mathrm{~nm}$ and they are able to enter the lungs. Some compounds in the particulates enter the blood and are transported to other parts of the body. Air pollution associated with vehicle emissions is a very significant global problem, and annual social costs are of the order of $\$ 3$ trillion with more than 3 million premature deaths per year associated with outdoor air pollution. The burden of disease on health that is partially attributed to air pollution includes cardiovascular disease, asthma, stroke, chronic obstructive pulmonary disease, lung cancer, dementia, multiple sclerosis, Parkinson's disease, autism in children, and childhood leukemia. Risks associated with low birth weight and early preterm delivery are greater for those living with higher levels of air pollution.

There are a number of actions that can be taken to improve air quality and health. The electrification of transportation and the transition to the generation of electricity with wind and solar energy are having significant impacts on improving air quality in California and some other parts of the world. Air pollution from coal combustion and industrial sources needs to be reduced in many locations. Electric buses are being purchased and put into service in the United States, Europe, and China. Electric taxi cabs provide another pathway to better air quality and health, and there is progress in their production and sales. More than 200 low emission zones have been established to improve air quality in regions of cities. Fees have been established and implemented to reduce congestion and vehicle emissions in some large cities.

Public education related to air pollution and health is important, and it is part of the process to improve health. Individuals can take action to reduce their exposure to air pollution including monitoring the air quality index, avoiding rush hour exposures, exercising in parks where particulate concentrations are lower, and filtering the air in their homes. Communities can take action to improve the quality of their air through public transport subsidization, promoting electric vehicles, and enhancing charging infrastructure for electric vehicles.

\section{Acknowledgements}

This publication was developed under Assistance Agreement RD83618201 
awarded by the U.S. Environmental Protection Agency to Kansas State University. It has not been formally reviewed by EPA. The views expressed in this document are solely those of the authors and do not necessarily reflect those of the Agency. EPA does not endorse any products or services mentioned in this publication.

\section{Conflict of Interest}

The authors do not have any conflict of interest.

\section{References}

[1] Abhijith, K.V., Kumar, P., Gallagher, J., McNabola, A. et al. (2017). Air Pollution Abatement Performances of Green Infrastructure in Open Road and Built-Up Street Canyon Environments. Atmospheric Environment, 162, 71-86.

https://doi.org/10.1016/j.atmosenv.2017.05.014

[2] ACS (2016) Diesel Exhaust and Cancer, American Cancer Society Report. https://www.cancer.org/

[3] AirNow (2017) Air Quality Index-A Guide to Air Quality and Your Health, AirNow. https://www.airnow.gov/

[4] Apte, J.S., Marshall, J.D., Cohen, A.J. and Bauer, M. (2015). Addressing Global Mortality from Ambient PM2.5. Environmental Science and Technology, 49, 8057-8066.

[5] Ayre, J. (2017) China 100\% Electric Bus Sales Grew to about 115,700 in 2016, Clean Technica. https://cleantechnica.com/

[6] Becerra, T.A., Wilhelm, M., Olsen, J., Cockburn, M., and Ritz, B. (2013) Ambient Air Pollution and Autism in Los Angeles County, California. Environmental Health Perspectives, 121, 380-386.

[7] Bereitschaft, B. (2015). Pedestrian Exposure to Near-Roadway PM2.5 in Mixed Use Urban Corridors: A case study of Omaha, Nebraska. Sustainable Communities and Society, 15, 64-74. https://doi.org/10.1016/j.scs.2014.12.001

[8] Bernatsky, S., Smargiassi, A., Johnson, M., et al. (2015). Fine Particle Air Pollution, Nitrogen Dioxide, and Systemic Autoimmune Rheumatic Disease in Calgary, Alberta. Environmental Research, 140, 474-478. https://doi.org/10.1016/j.envres.2015.05.007

[9] Bernatsky, S., Smargiassi, A., Barnabe, C., et al. (2016). Fine Particulate Air Pollution and Systemic Autoimmune Rheumatic Disease in Two Canadian Provinces. Environmental Research, 146, 85-91. https://doi.org/10.1016/j.envres.2015.12.021

[10] Block, M., Elder, A., Auten, R.L. et al. (2012). The Outdoor Air Pollution and Brain Health Workshop. NeuroToxicology, 33, 972-984. https://doi.org/10.1016/j.neuro.2012.08.014

[11] Boarnet, M.G., Houston, D., Edwards, R., et al. (2011) Fine Particle Concentrations on Sidewalks in Five Southern California Cities. Atmospheric Environment, 45, 4025-4033. https://doi.org/10.1016/j.atmosenv.2011.04.047

[12] Brugge, D., Durant, J.L. and Rioux, C. (2007) Near-Highway Pollutants in Motor Vehicle Exhaust: A Review of Epidemiologic Evidence of Cardiac and Pulmonary Health Risks. Environmental Health, 6, 23. https://doi.org/10.1186/1476-069X-6-23

[13] Brugge, D., Patton, A.P., Bob, A., et al. (2015) Developing Community Level Policy and Practice to Reduce Traffic-Related Air Pollution Exposure. Environmental Jus- 
tice, 8, 95-104. https://doi.org/10.1089/env.2015.0007

[14] Cacciottolo, M., Wang, X., Driscoll, J., et al. (2017) Particulate Airpollutants, APOE Alleles and Their Contributions to Cognitive Impairment in Older Women and to Amyloidogenesis in Experimental Models. Translational Psychology, 7, Article ID: e1022.

[15] Caiazzo, F., Ashok, A., Waite, I.A., et al. (2013) Air Pollution and Early Deaths in the United States. Part I. Quantifying the Impact of Major Sectors in 2005. Atmospheric Environment, 79, 198-208. https://doi.org/10.1016/j.atmosenv.2013.05.081

[16] CARB (2017) California's Advanced Clean Car Midterm Review, California Air Resources Board Report. http://www.arb.ca.gov/

[17] Cartier, Y., Benmarhnia, T. and Brousselle, A. (2015) Tool for Assessing Health and Equity Impacts of Interventions Modifying Air Quality in Urban Environments. Evaluation and Program Planning, 53, 1-9. https://doi.org/10.1016/j.evalprogplan.2015.07.004

[18] Chen, H., Kwong, J.C., Copes, R., et al. (2017) Living near Major Roads and the Incidence of Dementia, Parkinson's Disease, and Multiple Sclerosis: A Population-Based Cohort Study. Lancet, 389, 718-726. https://doi.org/10.1016/S0140-6736(16)32399-6

[19] CTA (2014) Electric Bus, Chicago Transit Authority. http://www.transitchicago.com/

[20] EC. (2017) Air Quality Standards, European Commission of the European Union. http://ec.europa.eu/

[21] Erickson, L.E. (2017) Reducing Greenhouse Gas Emissions and Improving Air Quality: Two Global Challenges. Environmental Progress and Sustainable Energy, 36, 982-988. https://doi.org/10.1002/ep.12665

[22] Erickson, L.E. and Jennings, M. (2017) Energy, Transportation, Air Quality, Climate Change, Health Nexus: Sustainable Energy Is Good for Our Health. AIMS Public Health, 4, 47-61. https://doi.org/10.3934/publichealth.2017.1.47

[23] Erickson, L.E., Robinson, J., Brase, G. and Cutsor, J., Eds. (2017) Solar Powered Charging Infrastructure for Electric Vehicles: A Sustainable Development. CRC Press, Boca Raton, Florida.

[24] Ewing, J. (2017) France Plans to End Sales of Gas and Diesel Cars by 2040. New York Times, 6 July 2017. https://www.nytimes.com/

[25] Feigin, V.L., Roth, G.A., Naghavi, M., et al. (2016) Global Burden of Stroke and Risk Factors in 188 Countries during 1990-2013: A Systematic Analysis for the Global Burden of Disease Study 2013. The Lancet Neurology, 15, 913-924. https://doi.org/10.1016/S1474-4422(16)30073-4

[26] Filippini, T., Heck, J.E., Malagoli, C., et al. (2015) A Review and Meta-Analysis of Outdoor Air Pollution and Risk of Childhood Leukemia. Journal of Environmental Science and Health C: Environmental Carcinogenesis Ecotoxicology Reviews, 33, 36-66. https://doi.org/10.1080/10590501.2015.1002999

[27] Fleischer, N.L., Merialdi, M., van Donkelaar, A., et al. (2014) Outdoor Air Pollution, Preterm Birth and Low Birth Weight: Analysis of the World Health Organization Global Survey on Maternal and Perinatal Health. Environmental Health Perspectives, 122, 425-430. https://doi.org/10.1289/ehp.1306837

[28] Frangoul, A. (2017) London's Black Cabs Are About to Turn Green Thanks to a New \$373 Million Electric Taxi Factory. CNBC. http://www.cnbc.com/

[29] Genc, S., Zadeoglulari, Z., Fuss, S.H. and Genc, K. (2012) The Adverse Effects of Air Pollution on the Nervous System. Journal of Toxicology, 2012, Article ID: 782462. 
https://doi.org/10.1155/2012/782462

[30] Ghosh, J.K.C., Heck, J.E., Cockburn, M., et al. (2013) Prenatal Exposure to Traffic-Related Air Pollution and Risk of early Childhood Cancers. American Journal of Epidemiology, 178, 1233-1239. https://doi.org/10.1093/aje/kwt129

[31] Giles, L.V., Barn, P., Kunzli, N., Romieu, I., et al. (2011) From Good Intentions to Proven Interventions: Effectiveness of Actions to Reduce the Health Impacts of Air Pollution. Environmental Health Perspectives, 119, 29-36. https://doi.org/10.1289/ehp.1002246

[32] Gulia, S., Nagendra, S.M.S., Khare, M. and Khanna, I. (2015) Urban Air Quality Management: A Review. Atmospheric Pollution Research, 6, 286-304. https://doi.org/10.5094/APR.2015.033

[33] Ha, S., Hu, H., Roussos-Ross, D., et al. (2014) The Effects of Air Pollution on Adverse Birth Outcomes. Environmental Research, 134, 198-204. https://doi.org/10.1016/j.envres.2014.08.002

[34] Health Effects Institute (2017) State of Global Air 2017. Health Effects Institute, Boston, MA. http://www.healtheffects.org/

[35] Heck, J.E., Wu, J., Lombardi, C., et al. (2013) Childhood Cancer and Traffic-Related Air Pollution Exposure in Pregnancy and Early Life. Environmental Health Perspectives, 121, 1385-1391. https://doi.org/10.1289/ehp.1306761

[36] Heydarpour, P., Amini, H., Khoshkish, S., et al. (2014) Potential Impact of Air Pollution On Multiple Sclerosis in Tehran, Iran. Neuroepidemiology, 43, 233-238. https://doi.org/10.1159/000368553

[37] Hitchcock, G. and Vedrenne, M. (2014) Cycling and Urban Air Quality. European Cyclists Federation. http://www.ecf.com/

[38] Holmes-Gen, B. and Barrett, W. (2016) Clean Air Future: Health and Climate Benefits of Zero Emission Vehicles. American Lung Association of California Report, Chicago.

[39] Hyland, J. and Donnelly, P. (2015) Air Pollution and Health: The Views of Policy Makers, Planners, Public and Private Sector on Barriers and Incentives for Change. Journal of Transport and Health, 2, 120-126. https://doi.org/10.1016/j.jth.2015.03.006

[40] IARC (2012) Diesel Engine Exhaust Carcinogenic, Press Release No. 213. International Agency for Research on Cancer, World Health Organization, Lyon.

[41] Jack, O. (2016) Electric Bus Developments in Europe. BUSRide. http://busride.com/

[42] Janhall, S. (2015) Review on Urban Vegetation and Particle Air Pollution: Deposition and Dispersion. Atmospheric Environment, 105, 130-137. https://doi.org/10.1016/j.atmosenv.2015.01.052

[43] Kan, H., Chen, B. and Hong, C. (2009) Health Impact of Air Pollution in China: Current Knowledge and Future Research Needs. Environmental Health Perspectives, 117, A187. https://doi.org/10.1289/ehp.12737

[44] Klejnowski, K., Krasa, A., Rogula-Kozlowska, W. and Blaszczak, B. (2013) Number Size Distribution of Ambient Particles in a Typical Urban Site: The First Polish Assessment Based on Long-Term (9 Months) Measurements. The Scientific World Journal, 2013, Article ID: 539568. https://doi.org/10.1155/2013/539568

[45] Krzyzanowski, M., Apte, J.S., Bonjour, S.P., et al. (2014) Air Pollution in the Mega-Cities. Current Environmental Health Reports, 1, 185-191. https://doi.org/10.1007/s40572-014-0019-7

[46] Kuuluvainen, H., Ronkko, T., Jarvinen, A., et al. (2016) Lung Deposited Surface 
Area Size Distribution of Particulate Matter in Different Urban Areas. Atmospheric Environment, 136, 105-113. https://doi.org/10.1016/j.atmosenv.2016.04.019

[47] Lambert, F. (2017) Seattle Is Getting a Massive Fleet of All-Electric Buses, Proterra Gets the Bulk of the Order. Electrek. https://electrek.co

[48] Lelieveld, J., Evans, J.S., Fnais, M., et al. (2015) The Contribution of Outdoor Air Pollution to Premature Mortality on a Global Scale. Nature, 525, 367-371. https://doi.org/10.1038/nature15371

[49] LeSage, J. (2017) Beijing Cab Operators Converting to Electric Taxis. Hybrid Cars. http://www.hybridcars.com/

[50] Liu, C. (2016) Electric Bus Pioneer Pulls into Wider European Market. China Daily. http://www.chinadaily.com.cn/

[51] Mani, M.S., Sandhu, S.C., Joshi, G., et al. (2013) India: Diagnostic Assessment of Select Environmental Challenges, Report No. 70004-IN. World Bank, South Asia Region.

[52] McDonald, Z. (2016) Electric Taxis Are on Their Way. Fleet Carma. http://www.fleetcarma.com/

[53] Mehrpour, M., Shams-Hosseini, N.S., Rezaali, S., et al. (2013) Effect of Air Pollutant Markers on Multiple Sclerosis Relapses. Iranian Journal of Public Health, 42, 1167-1173.

[54] Meltzer, S. (2014) Six Things All Cities Should Be Doing to Reduce Urban Air Pollution Now. Urban Times. https://urbantimes.com/

[55] Morello-Frosch, R., Jesdale, B.M., Sadd, J.L. and Pastor, M. (2010) Ambient Air Pollution Exposure and Full-Term Birth Weight in California. Environmental Health, 9, 44. https://doi.org/10.1186/1476-069X-9-44

[56] Morello-Frosch, R. and Shenassa, E.D. (2006) The Environmental Riskscape and Social Inequality: Implications for Explaining Maternal and Child Health Disparities. Environmental Health Perspectives, 114, 1150-1153. https://doi.org/10.1289/ehp.8930

[57] Mousavi, S.E., Heydarpour, P. and Reis, J. (2017) Multiple Sclerosis and Air Pollution Exposure: Mechanisms toward Brain Autoimmunity. Medical Hypotheses, 100, 23-30. https://doi.org/10.1016/j.mehy.2017.01.003

[58] OECD (2016) The Economic Consequences of Outdoor Air Pollution. OECD Publishing, Paris.

[59] O'Gorman, C., Lucas, R. and Taylor, B. (2012) Environmental Risk Factors for Multiple Sclerosis: A Review with a Focus on Molecular Mechanisms. International Journal of Molecular Sciences, 13, 11718-11752. https://doi.org/10.3390/ijms130911718

[60] Oikonen, M., Laaksonen, M., Oksaranta, O., et al. (2003) Ambient Air Quality and Occurrence of Multiple Sclerosis Relapse. Neuroepidemiology, 22, 95-99. https://doi.org/10.1159/000067108

[61] Oudin, A., Forsberg, B., Adolfsson, A.N., et al. (2016) Traffic-Related Air Pollution and Dementia Incidence in Northern Sweden: A Longitudinal Study. Environmental Health Perspectives, 124, 306-312.

[62] Pattekar, S. (2017) Combating Pollution in Los Angeles: How One City Is Improving Air Quality. My Sidewalk. https://blog.mysidewalk.com/

[63] Peters, J., Theunis, J., Van Poppel, M., et al. (2013) Monitoring PM 10 and Ultrafine Particles in Urban Environments Using Mobile Measurements. Aerosol and Air Quality Research, 13, 509-522. 
[64] Petroff, A. (2017) These Countries Want to Ditch Gas and Diesel Cars. Money, CN News. http://money.cnn.com/

[65] Prince, M., Comas-Herrera, Knapp, M., et al. (2016) World Alzheimer Report 2016. Alzheimer's Disease International. http://www.alz.co.uk

[66] Raz, R., Roberts, A.L., Lyall, K., Hart, J.E., Just, A.C., Laden, F. and Weisskopf, M.G. (2015) Autism Spectrum Disorder and Particulate Matter Air Pollution before, during and after Pregnancy: A Nested Case-Control Analysis within the Nurses' Health Study II Cohort. Environmental Health Perspectives, 123, 264-270.

[67] Ridlington, E. and Madsen, T. (2017) Our Health at Risk. Environment Illinois Research and Education Center. http://www.environmentillinoiscenter.org/

[68] Ritz, B., Lee, P.C., Hansen, J., et al. (2016) Traffic Related Air Pollution and Parkinson's Disease in Denmark: A Case Control Study. Environmental Health Perspectives, 124, 351-356.

[69] Roberts, A.L., Lyall, K., Hart, J.E., Laden, F., Just, A.C., et al. (2013) Prenatal Air Pollutant Exposures and Autism Spectrum Disorder in the Children of Nurses Health Study II Participants. Environmental Health Perspectives, 121, 978-984.

[70] Rohtaki, H. (2017) LED Boards Set Up at Five Spots to Display Air Quality Index. Indian Express, 6 June 2017. http://indianexpress.com

[71] Rowe, D.B. (2011) Green Roofs as a Means of Pollution Abatement. Environmental Pollution, 159, 2100-2110. https://doi.org/10.1016/j.envpol.2010.10.029

[72] Salmond, J.A., Tadaki, M., Vardoulakis, S., et al. (2016) Health and Climate Related Ecosystem Services Provided by Street Trees in the Urban Environment. Environmental Health, 15, 95-111. https://doi.org/10.1186/s12940-016-0103-6

[73] ScienceNordic (2015) Twelve Things That Can Protect You from Polluted Urban Air. http://sciencenordic.com/

[74] Shandas, V., Voelkel, J., Rao, M. and George, L. (2016) Integrating High Resolution Data Sets to Target Mitigation Efforts for Improving Air Quality and Public Health in Urban Neighborhoods. International Journal of Environmental Research and Public Health, 13, 790. https://doi.org/10.3390/ijerph13080790

[75] Sun, G., Hazlewood, G., Bernatsky, S., et al. (2016) Association between Air Pollution and the Development of Rheumatic Disease: a Systematic Review. International Journal of Rheumatology, 2016, Article ID: 5356307. https://doi.org/10.1155/2016/5356307

[76] TfL (2016) Mayor Unveils First Fully Electric Bus Routes for Central London, Transport for London. https://tfl.gov.uk/

[77] Trasande, L., Malecha, P. and Attina, T.M. (2016) Particulate Matter Exposure and Preterm Birth: Estimates of U.S. Attributable Burden and Economic Costs. Environmental Health Perspectives, 124, 1913-1918. https://doi.org/10.1289/ehp.1510810

[78] Turpen, A. (2015) Nissan Now Has More Than 550 Electric Taxi Cabs on the Road in Europe, Torque New. http://www.torquenews.com/

[79] Underwood, E. (2017) The Polluted Brain. Science, 355, 342-345. https://doi.org/10.1126/science.355.6323.342

[80] UNICEF (2016) Clear the Air for Children: The Impact of Air Pollution on Children. United Nations International Children's Emergency Fund Report, UNICEF, New York. http://www.unicef.org/

[81] United Nations (2005) Urban Air Quality Management Toolbook. United Nations Environment Program, Nairobi. 
[82] U.S. EPA (2012) Air Climate and Energy: Strategic Research Action Plan 2012-2016. EPA 601/R-12/003/June 2012. http://www.epa.gov/

[83] U.S. EPA (2014) National Air Toxics Program: The Second Integrated Air Toxics Report to Congress, EPA-456/R-14-001. http://www.epa.gov/

[84] U.S. EPA (2015) Air, Climate, and Energy: Strategic Research Action Plan 2016-2019, EPA 601/K-15/005/November 2015. http://www.epa.gov/

[85] U.S. EPA (2016a) Technical Assistance Document for the Reporting of Daily Air Quality-The Air Quality Index (AQI). U.S. Environmental Protection Agency.

http://www.epa.gov/

[86] U.S. EPA (2016b) EPA Awards \$4.5 Million to Advance Air Monitoring Technology. U.S. Environmental Protection Agency.

https://www.epa.gov/newsreleases/epa-awards-45-million-advance-air-monitoringtechnology

[87] U.S. EPA (2017) National Ambient Air Quality Standards Table. U.S. Environmental Protection Agency. http://www.epa.gov/

[88] Voelker, J. (2017) London's \$27 Entry Charge for Pre-2016 Diesel Cars to Start April 2019, Green Car Reports. http://www.greencarreports.com/

[89] Vojinovic, S., Savic, D., Lukic, S., et al. (2015) Disease Relapses in Multiple Sclerosis Can Be Influenced by Air Pollution and Climate Seasonal Conditions. Vojnosanitetski Pregled, 72, 44-49. https://doi.org/10.2298/VSP140121030V

[90] Volk, H.E., Hertz-Picciotto, I., Delwiche, L., Lurmann, F. and McConnell, R. (2011) Residential Proximity to Freeways and Autism in the CHARGE Study. Environmental Health Perspectives, 119, 873-877. https://doi.org/10.1289/ehp.1002835

[91] Wang, X., Ding, H., Ryan, L. and Xu, X. (1997) Association between Air Pollution and Low Birth Weight: A Community Based Study. Environmental Health Perspectives, 105, 514-520. https://doi.org/10.1289/ehp.97105514

[92] Wang, L., Zhong, L., Vardoulakis, S., et al. (2016) Air Quality Strategies on Public Health Equity in Europe: A Systematic Review. International Journal of Environmental Research and Public Health, 13, 1196. https://doi.org/10.3390/ijerph13121196

[93] WAQI (2017) Real Time Air Quality Index, Air Pollution in the World. The World Air Quality Index Project.

[94] WHO (2016) India Takes Steps to Curb Pollution. Bulletin of the World Health Organization, 94, 487-488. https://doi.org/10.2471/BLT.16.020716

[95] Williams, R., Kilaru, V., Snyder, E., et al. (2014) Air Sensor Guidebook. U.S. Environmental Protection Agency, Washington DC.

[96] World Bank (2016) The Cost of Air Pollution: Strengthening the Economic Case for Action. World Bank Report, Washington DC.

[97] Xue, J., Li, Y., Wang, X., et al. (2015) Comparison of Vehicle Exhaust Particle Size Distributions Measured by SMPS and EEPS during Steady State Conditions. Aerosol Science and Technology, 49, 984-996. https://doi.org/10.1080/02786826.2015.1088146

[98] Zeft, A.S., Prahalad, S., Schneider, R., et al. (2009) Juvenile Idiopathic Arthritis and Exposure to Fine Particulate Air Pollution. Clinical and Experimental Rheumatology, 27, 877-884.

[99] Nelson, L.J. and Reyes, E.A. (2017) Metro Agrees to Buy 95 Electric Buses, in the First Step toward an Emissions-Free Fleet. Los Angeles Times, 27 July 2017. 
Submit or recommend next manuscript to SCIRP and we will provide best service for you:

Accepting pre-submission inquiries through Email, Facebook, LinkedIn, Twitter, etc. A wide selection of journals (inclusive of 9 subjects, more than 200 journals)

Providing 24-hour high-quality service

User-friendly online submission system

Fair and swift peer-review system

Efficient typesetting and proofreading procedure

Display of the result of downloads and visits, as well as the number of cited articles Maximum dissemination of your research work

Submit your manuscript at: http://papersubmission.scirp.org/

Or contact jep@scirp.org 